\title{
Simmel and his lectures on education in the context of German progressive education
}

\author{
Gonon, Philipp
}

\begin{abstract}
Georg Simmel is not really known for his pedagogical writing. Indeed, it did not represent his main focus, which was located in philosophy and sociology. The formation of a specific pedagogical science on a university level with its status of being an independent discipline happened only in the beginning of the 20th century: exactly at the same time when Georg Simmel was giving his lectures on Schulpädagogik (Lectures on Pedagogy for Schools) for teachers at the University of Strasbourg. It was also the time when progressive education became an international movement, aiming at activity, creativity, childcenteredness and youth activities in communities and nature. This article sketches Simmel's approach towards pedagogy in terms of disciplinary thinking as well as his understanding of how teachers should behave in schools. A further aspect is the potential of his thinking for a theory of education (Bildung).
\end{abstract}

DOI: https://doi.org/10.7202/1062540ar

Posted at the Zurich Open Repository and Archive, University of Zurich

ZORA URL: https://doi.org/10.5167/uzh-182601

Journal Article

Published Version

Originally published at:

Gonon, Philipp (2019). Simmel and his lectures on education in the context of German progressive education. Simmel Studies, 23(1):89-107.

DOI: https://doi.org/10.7202/1062540ar 


\section{Simmel Studies}

\section{Simmel and his Lectures on Education in the Context of German Progressive Education}

\section{Philipp Gonon}

Simmel as Educator

Volume 23, numéro 1, 2019

URI : https://id.erudit.org/iderudit/1062540ar

DOI : https://doi.org/10.7202/1062540ar

Aller au sommaire du numéro

Éditeur(s)

Georg Simmel Gesellschaft

ISSN

1616-2552 (imprimé)

2512-1022 (numérique)

Découvrir la revue

Citer cet article

Gonon, P. (2019). Simmel and his Lectures on Education in the Context of German Progressive Education. Simmel Studies, 23 (1), 89-107.

https://doi.org/10.7202/1062540ar
Résumé de l'article

Georg Simmel is not really known for his pedagogical writing. Indeed, it did not represent his main focus, which was located in philosophy and sociology. The formation of a specific pedagogical science on a university level with its status of being an independent discipline happened only in the beginning of the 20th century: exactly at the same time when Georg Simmel was giving his lectures on Schulpädagogik (Lectures on Pedagogy for Schools) for teachers at the University of Strasbourg. It was also the time when progressive education became an international movement, aiming at activity, creativity, child-centeredness and youth activities in communities and nature. This article sketches Simmel's approach towards pedagogy in terms of disciplinary thinking as well as his understanding of how teachers should behave in schools. A further aspect is the potential of his thinking for a theory of education (Bildung). 


\title{
PHILIPP GONON
}

\section{Simmel and his Lectures on Education in the Context of German Progressive Education}

\begin{abstract}
Georg Simmel is not really known for his pedagogical writing. Indeed, it did not represent his main focus, which was located in philosophy and sociology. The formation of a specific pedagogical science on a university level with its status of being an independent discipline happened only in the beginning of the 20th century: exactly at the same time when Georg Simmel was giving his lectures on Schulpädagogik (Lectures on Pedagogy for Schools) for teachers at the University of Strasbourg. It was also the time when progressive education became an international movement, aiming at activity, creativity, child-centeredness and youth activities in communities and nature. This article sketches Simmel's approach towards pedagogy in terms of disciplinary thinking as well as his understanding of how teachers should behave in schools. A further aspect is the potential of his thinking for a theory of education (Bildung).
\end{abstract}

The answer why Georg Simmel was engaged in Education and Pedagogy is perhaps quite simple: as a university professor for philosophy, he had to. In Strassburg, where his short career as a full professor came to an end, one of his duties was to teach future teachers. This task was part of an educational training for teachers mainly aimed at the Gymnasium (High School). The expectation for philosophers at university to deliver lectures in pedagogy is based on a longstanding German tradition: Kant and others, they all had as well been giving lessons in education. Some of these philosophers were afterwards even more renowned for their pedagogical writings, like Johann Friedrich Herbart or Friedrich Paulsen or later on Eduard Spranger.

Nevertheless, the formation of a specific pedagogical science on a university level with its status of being an independent discipline 
and a specialized teaching staff in universities happened only in the beginning of the $20^{\text {th }}$ century: exactly at the same time when Georg Simmel was giving his lectures on "Schulpädagogik" (Lectures on Pedagogy for Schools). It was also the time when progressive education became an international movement, aiming at activity, creativity, child-centeredness and youth activities in communities and nature. This article sketches Simmel's approach towards pedagogy in terms of disciplinary thinking as well as his understanding of how teachers should behave in schools. A further aspect is the potential of his thinking for a theory of Bildung.

\section{The status of educational theory and the role of Simmel}

In the case of Georg Simmel, the question arises if he understood himself as a philosopher or as a sociologist or as something else, like a pedagogue. The disciplinary status of his thinking was already raised at his time and is often raised still today. Simmel's interdisciplinary approach, which meant to ignore the strict boarders of these disciplines, was one of his specific trademarks. Exactly this lack of assignability was also one of the problems of his career. As he writes in one of his letters of 1915 to the philosopher Heinrich Rickert:

There is a circle of sayings about me about everything that I am and am not, can and can't - and whenever it comes to considerations of faculties and governments about me $[. .$.$] soon$ I am too one-sided, soon too versatile, here actually only "sociologist" [...] there only critical and negating (GSG 23: 587).

Thus, it is also an open question how to locate his "school pedagogy” („Schulpädagogik“) which was part of his Strassburg lectures and was published after his death in 1922. The editor pointed out that Simmel did not intend to publish the lectures in their form at that time but wanted to elaborate them further. This did not happen anymore, since he fell ill in 1918 and died. 
Simmel's Lectures on Education were a minor area in his oeuvre but an important part of his Strassburg-profile, which included besides philosophy also pedagogy. Obviously in Educational Science he has not a reputation or a name in this field like other thinkers and public figures, like for today Jürgen Habermas and Niklas Luhmann.

The interesting question is why - at a first glance - are these lectures so differently related to his other works or writings? The lectures aim at a practical habitus of teaching: teachers should be supplied with useful hints and they should take principled action. How was this approach related to the state of the art of his time? Did he refer to other pedagogues and other concepts? I will try to tackle these questions in the first part of this article.

The task to bring education and pedagogy closer to future teachers, who at universities were studying subjects like modern languages, or latin, history or philosophy, implied that education often was seen more as an applied knowledge or practical wisdom and not as a highly rated science.

This assessment of education as a body of knowledge was also the starting point for Simmel's Lectures on Pedagogy for Schools ("Schulpädagogik"). The first remarks in the introduction aim to clarify the status of educational theory as a science and frame the other chapters, of which the first and longest one tackles fundamental questions. His first question is therefore if pedagogy is a science. He stresses as the point of science the way of thinking and the procedure at university: reflecting and giving lectures about a practical subject like teaching is science. In other words: the object of science is not, or not necessarily, science itself. Education as a science is not knowledge for its own sake but specific insofar as its aims should be the basis for practice. That is why Georg Simmel is not inclined to develop formal concepts and a theory of final destinations, what is, in his view, happening to an exaggerated degree in pedagogical literature. Basic issues should not be discussed for the thousandth time (Simmel 1922: 2). However, his approach 
is not meant to deliver just practical hints but a pedagogical attitude based on educational science.

This position was not at all mainstream in educational circles. Particularly Germany in those days was a territory where progressive education was a much debated public issue. In arteducation it was stated that the new pedagogy had to develop the "inner" value of children. Instead of copying natural or classical templates, children and young adults should develop their potential creativity. This was of high value not just for personal fulfillment but also for society, as a famous author in his book "Ways and Goals of Dilettantism" pointed out to (Lichtwark 1894). These considerations were far from university and from the endeavor to establish education as a disciplinary subject. A lot of other pedagogues like Hermann Lietz, Paul Geheeb saw as a first aim to establish practical school-experiments and land reform homes, inspired by the anti-authoritarian experiments in other countries. Others tried to establish a new pedagogy for life, work and a new community: a new direction in schools and in youth and adult education. Common ground was a liberal basic attitude which should pave the way for a creative, self-confident youth who represented the future workers and leaders for a new nation. Science was not included in these considerations.

Georg Simmel, however, was far away from such practical claims and concepts and focused on university, although he took notice also of these developments. But his main concern was the building of a new approach to society and individuality in a scientific and philosophical manner.

In Simmel's correspondence, we find answers about his selfunderstanding related to sciences. In the early 1910s he was a member and an important co-organizer of the meetings of the emerging DSG ("Deutsche Gesellschaft für Soziologie"). These reunions brought together a lot of sociologists. It was the time when sociology formed itself as a university discipline. However, there were quite a lot of controversies which led to splits and factions. After Paul Barth had delivered a lecture at the second meeting of 
the DSG in Berlin 1912, he was heavily criticized by Max Weber for his strong moral adherence of his paper about nationalism.

Simmel quit this organizational network after a first engaged period, saying that he was first and foremost a philosopher. Especially his call to Strasburg enforced his decision. He had to leave his beloved Berlin and started in a marginal area of the German Empire. Strasburg was also a Catholic area, a point which initially was also an issue for him, related to his philosophical and pedagogical standpoint.

In the same line has to be seen Simmel's engagement for keeping philosophical chairs at universities alive. He was an initiator of a manifesto demanding that chairs of philosophy do not have to be redefined as experimental psychology, as it seemed to be more and more the case out of the debate of finding a successor for Hermann Cohens' chair, a distinguished philosopher in Marburg in 1913 (see Rammstedt \& Rammstedt 2008: 176).

In his exchanges of letters, we find only rare links to (reform)pedagogues of his time. Furthermore, he did not tackle educational problems in his correspondence with still today prominent partners like Bergson, Rodin and Rilke, Gundolf and Kracauer, besides his colleagues from sociology or philosophy, like Weber, Jaspers and Rickert.

The only exception is Georg Kerschensteiner. The few pedagogues with whom he corresponded play a marginal role in his exchanges of letters: to Aloys Fischer he just wrote a thank you for sending him his publication. Also, the correspondence with Paul Natorp, who was active in the German "Jugendbewegung" (youth movement) and besides his core philosophical work an active publisher of educational writings, was addressed to a philosophical colleague and contained only a few words about exchanging books as gifts.

If we compare what other philosophers in his position at his time did when they were expected to teach pedagogy, we can observe that especially Neo-Kantian philosophers were presenting a 
systematic pedagogy at the same time when Simmel delivered his lectures, ranging from Richard Hönigswald and Jonas Cohn to Paul Natorp.

Leonard Nelson, also like Natorp very close to Socialism and an adherent of the Marburg school of Neo-Kantianism, tried to establish, in his lectures of 1916, 1920 and 1924, a "system of philosophical ethic and pedagogy" in the spirit of Kant. Pedagogy was defined as a "philosophical pedagogy" which had to be grounded in ethics. The aim was to establish a system of consistency which included a formal and material pedagogy in order to establish a practical and applicable pedagogy (Nelson 1949: 337).

Jonas Cohn in the introductory chapter to his "Spirit of Education - Pedagogy on philosophical grounds" (1919) describes his goal: to bring in a theoretical ground in the field of youth education. According to him, the first theory was developed by Plato. Nevertheless, it is visible that he was affected by the "Jugendbewegung" when he describes enthusiasm ("Begeisterung") as a key to education. Besides new and old heroes like John Locke and Jean-Jacques Rousseau, he remembers to rely also on Johann Friedrich Herbart (Cohn 1919: 3). Also, his endeavor was to clarify the principles of education. That is why the finding and defining of central concepts was so important in order to justify and build up education as a science (Ibid., 14).

All in all, the "pedagogical movement" with its focus on art, youth and specific boarding schools did not very much affect pedagogical teaching at universities (see also Ritzel 1980).

As well Richard Hönigswald, who was a professor of philosophy and pedagogy at the university of Breslau, saw in his lectures, first published in 1917, the main task in establishing the systematic grounds for a pedagogy at university level: a difficult task in times when pedagogy was in the center of cultural policy, as he remarked (Hönigswald 1927: 11). In his view, educational theory at university has to focus on conceptualization and has to take a critical distance to life ("Leben"), whereas other institutions, e.g. for teacher training, 
should be more concerned about practical matters (Hönigswald 1966, S. 2).

Another scholar, a student of Wilhelm Dilthey, one of the founders of "Geisteswissenschaften", Max Frischeisen-Köhler, discussed the possibility to ground pedagogy in a systematic theory of Bildung. Ideal values have to be confronted with empirical realities, which gives ethics a specific, but not exclusive role (1962: 90). Max Frischeisen-Köhler, who analyzed Simmel's work and his metaphysics about life quite carefully, saw a closeness of Simmel's approach to his own, which Simmel unfortunately could not develop further, due to his early death in 1918 (Frischeisen-Köhler 1921).

Furthermore, also Paul Barth tried to clarify the position and scientific value of pedagogy. In his history of education, based on a sociological and historical perspective, he criticized Simmel for his descriptive approach, which is based on apt individual observations but underestimates the historical dimension as an integral aspect of a topical situation (Barth, 1925: 44). Barth's elements of a theory of education and teaching, based on his work as a professor of philosophy and education at the university of Leipzig, was dedicated to progressive education, namely to Georg Kerschensteiner. Nevertheless, Barth still adheres to the concept of the great opponent of progressive education, Herbart's educational teaching ("erziehender Unterricht") as a core of pedagogical theory and science. But on the other hand, he tried to integrate new psychological and philosophical knowledge (Barth, 1912: 2). Pedagogy itself was, in his view, not a general science but had to be adapted to each specific society (ibid., 6). Another twist in order to legitimize pedagogy as a science and a practical tool was initiated by Paul Natorp.

Natorp, who taught philosophy and pedagogy at the university of Marburg, was one of the pillars of the so called neo-Kantian school of Marburg. He attempted to justify pedagogy in the social sphere already in his early writings. Natorp criticized the narrow focus of pedagogy on school and family and committed himself to 
a pedagogy that strived for will-based education rooted in the community. Social pedagogy was therefore in front position against Herbartianism, as well as against a psychologically based pedagogy based on general principles (Natorp 1904). Philosophy which, in his view, was much broader than ethics and a psychology which should be critical and much broader than psychology towards teaching, as he pointed out with much verve against Herbartian scholars, is the basis of educational science (Natorp 1912). In his guiding principles for pedagogy, first published in 1905, he explicitly stated that pedagogy is more than practical wisdom but as well a science (Natorp 1909).

This struggle for the scientific character and function of pedagogy in the higher education sector also shaped the remarks of Erich Stern, who taught pedagogy in Giessen. He referred strongly to Simmel in his remarks and advocated for a pedagogy which was based on the humanities. The same should apply even for psychology, which should not be grounded in experiment (Stern, 1922: VI).

All in all, the way of viewing education and establishing pedagogy on a university level was an issue which a lot of university professors, mainly located in philosophy, preoccupied. In contrast to his colleagues, Simmel did not aim to establish a systematic disciplinary focus. Also, his connections with the pedagogical movement or with other pedagogues and even philosophers teaching pedagogy on university level were quite weak. Instead he seemed to focus on a professional attitude of teachers. Simmel was definitely not seen as a pedagogue by his colleagues. Thus, even in publications about the teacher he is not present. If you find a reference to him, like in "The tasks of teachers in higher education" where the author discusses the authority of a teacher, the ideas are picked from Simmel's sociology (Jerusalem, 1912: 230). 


\section{The content and aim of Simmel's Lectures on Pedagogy for Schools ("Schulpädagogik")}

According to the editor, the lectures were to have an effect "exclusively on the fundamental attitude" with which the young generation of teachers would approach their task. Instead of general exhortations, it would be a matter of illuminating and creating concrete concepts (Hauter, 1922: IV). The lessons dealt with the classical problem of tackling the issue of individualization and personality development („Persönlichkeitsbildung”) on the one hand and socialization on the other hand (Rodax, 1999: 9).

In his first and longest of ten lectures and a supplementary annex about sexual pedagogy Simmel scrutinizes the existent body of pedagogical knowledge with regard of teaching and schools. He is - like a lot of colleagues of his times - critical about the longstanding tradition of the Herbartians, like Moritz Wilhelm Drobisch, Karl Volkmar Stoy, Tuiskon Ziller, Theodor Vogt, Otto Willmann and many others. It was Herbart who founded the "Herbart School" which was based on his philosophy, his ideas about psychology and ethics. The Herbartians developed a whole range of principles for teaching. Until the end of the $19^{\text {th }}$ century they were a very influential movement for teachers and schools in Germany and beyond. Simmel is not - as other reformers - attacking the concept of the Herbartians directly. Nevertheless, he criticizes the discourse of defining and redefining stages and ways - as they often do - of teaching. On the other hand, also in his other writings Simmel referred to Herbart whom he saw as a forerunner or founder of modern psychology.

Simmel states that school and teachers have to be lively ("lebendig") and creative. For him, the Herbartian principles were too narrow, too far away from "life". This sounds very much as if the progressive educationalists were positioning themselves. But his references were not at all authors of progressive education. He referred to sociologist and philosopher Paul Barth, who was the author of a range of books including education. Also, frequently 
quoted is Friedrich Regener who explicitly criticized progressive education. Two aspects were in the foreground: progressive education is too romantic when it comes to the image of children, and the theories are characterized by a lacking relation to society. So, Simmel's position towards progressive education and Herbartianism as two contradicting currents is interesting. On the one hand, he is opposing Herbartianism, on the other hand he is integrating this perspective in his lectures. He is against a specifically moral education as a specific subject in order to build up a strong ethic disposition ("Gesinnung"), as he points out in his last lecture (Simmel, 1922: 114). On the other hand, he confirms the strong role of the teacher as a role model, thus following the Herbartian tradition.

Against the "old pedagogy", which is still quite present as he remarks, he argues that - based on a Christian tradition of original sin ("Erbsünde") - a pessimistic view on children and their development is dominant. But there also exists an exaggerated idealism ("überspannter Idealismus") which looks at a child as a holy person. Both traditions are nowadays confronted with a new, modern principle of development (Ibid., 115). In this regard, he refers to Ernst Meumann who was the leading researcher in the field of experimental education, which was strongly rooted in the new psychology.

All in all, Simmel does not much refer to new research in the topical debate of his times about education in his lectures, as long as they do not support a principle-based position he would like to bring closer to the future teachers. The first chapters are rather dealing with general problems of teaching, like the problem of attention (chapter 2), consistency in the classroom (3), asking questions (4), the assessment of student performance and evaluation (5) and the question of punishment (6) as well as the last part about moral education (10). The next chapters about language (7), about the German essay (8), about teaching history and moral education (9) are meant for high school teachers. As well the annex 
about the task that schools should include sexual education, seems to focus on the German Gymnasium.

What these chapters reveal is the teacher-centeredness of his lectures. He gives a lot of hints at how teachers should teach and what attitudes they should take into account in the light of the task to teach students. Furthermore, it seems as if he did not aim - from a topical standpoint - to teach his students critical or radical thinking. His positions are very much stressing the existing curriculum the future teachers should adhere to. Subjects which are in the curriculum should be taught without reservations. If things are questionable, they nevertheless should be tackled straight forward; teachers have to obey to the curriculum. Also, there is not much sympathy for proletarians, who lack education. The task of teaching is exactly to supply young people with the prescribed knowledge. His approach is, all in all, surprisingly conformist.

\section{Theory of Bildung or the controversy with Georg Kerschensteiner}

The lessons about Lectures on Pedagogy for Schools do not reveal a theory of Bildung (liberal education). As discussed before, Georg Simmel is much more oriented towards a teacher who fulfills his tasks. A more general concept of the aim of education and a theory of Bildung related to schools is lacking. Nevertheless, in the correspondence with one pedagogue such questions are touched, at least.

Thus, the only interesting and explicit exchange related to pedagogy was by mail. It is not surprisingly that Georg Kerschensteiner, a very prominent progressive educationalist in his times and advocate of the internationally widely discussed "activity school", among them John Dewey, did refer to Simmel as a philosopher. Also, Kerschensteiner got some philosophical training by a Kantian philosopher and pedagogue: Hans Cornelius, who in the beginning of his career taught philosophy at Munich University. Georg Kerschensteiner felt much inspiration for his own theory of 
Bildung in relation with this philosophical discourse, among them Heinrich Rickert. Common ground were some Kantian approaches. Especially also Eduard Spranger, who in the following years developed into the most influential pedagogue for his discipline and the public, was important and was more or less engaged in this same kind of thinking, however connecting it closer to a theory of Bildung (Spranger 1909).

But Georg Simmel did not make references to these approaches nor to Eduard Spranger. The writings of pedagogues did really not belong to Simmel's body of references.

On the other hand, Simmel was noticed by several pedagogues, mostly his writings about sociology or "Lebensphilosophie". In Georg Kerschensteiner's oeuvre, a more pragmatic and progressive perspective was in the foreground at the beginning of his career (see Gonon 2009). Later, however, he tried to ground his theoretical approach in an axiomatic manner and in a theory of Bildung. That is why philosophers like Freyer, Litt, Rickert, Simmel, Spranger and Windelband played a more decisive role for his writings, as he remarks in his autobiographical sketch published in 1926 (Kerschensteiner, [1926] 1982: 140).

In contrast to often emphasized connections with Eduard Spranger and his relation to John Dewey's pragmatism, the secondary literature on Kerschensteiner contains only few references to the influence of the philosophy of life (Lebensphilosophie), especially currents shaped by the ideas of Georg Simmel. However, we know from his autobiographical sketch that Kerschensteiner dealt with Simmel's thinking when he developed his theory of education (Kerschensteiner 1982). Simmels' Lebensphilosophie was a kind of intellectual debate referring to German classicism, also a preferred legitimation background for Kerschensteiner. Simmel's writings about Goethe emphasize the close link between experience and creativity, as exemplified in Goethe's personality. The great classical author is lauded as a paragon of German culture, as its greatest 'hero', genius and artist, who was able to bring in his personality and shape the world in 
permanent interaction, as he writes in his bestseller, simply titled "Goethe" (Simmel 1918).

Georg Kerschensteiner felt inspired by Georg Simmel. Simmel himself wrote in 1917, after having received an author's copy of Kerschensteiner, that he knew and estimated the writings of Kerschensteiner, pointing out that since World War I he (Simmel) had had the obligation to give lectures on "Schulpädagogik". That is why in the past years he had been - according to this letter engaged in reading the publications of Kerschensteiner.

As a reader today you bear in mind how and in which way? It didn't seem to leave much of a mark. The aspect Georg Simmel stresses is youth education, but his lectures rather aim at teachers. Probably he was developing some new thoughts which were not yet ready for presentation.

Over the years, Kerschensteiner's activity school, conceived as a reform program against the 'book school', shifted its critical emphasis from the introduction of manual activity to facilitating and organizing education in a more encompassing sense of Bildung. Work as a contribution to reinvigorating school was not clearly distinguished from that broader aim; rather, as a method and goal it was at the same time in keeping with its curriculum. If the pupil acquired the subject matter - whether meant for the head or the hand, or manual and mental at the same time - and if there was an adequate balance between individual life and objectivation, then according to Kerschensteiner's theorizing - access to agents and vessels of value was possible. What is decisive is "that all procedure in pedagogy is only meaningful if it leads to some meaning in life. But the meaning of life means that life is related to a lasting, unconditional, timeless value" (Kerschensteiner, 1926: 78).

Georg Simmel is stressing in his writing, however, rather a political than a theoretical problem when it comes to pedagogy. $\mathrm{He}$ writes that educating the youth is an urgent problem and the current German distress (in the year 1918) makes it important to put his modest individual power in teacher training in order to help develop 
the future of Germany. Simmel's aim is to help teachers to develop a pedagogical attitude and mark a distance to an education for the future. School organization and curricula are taken as given. His main focus is on how teaching can happen in a way that it is (also) education and on how to develop personality in a system which is indifferent to such an aim (GSG 23: 843 f.).

In the following sentences Georg Simmel marks his differences to the approach of Georg Kerschensteiner. The difference is seen in the way in which Kerschensteiner thinks to enable Bildung. His view is to individualize the subject matter the pupil is confronted with. Simmel, however, sees the main point in individualizing the pupils' learning (Ibid., 844).

In contrast to Kerschensteiner, Simmel stresses individuality in the social function. One main problem of school is to transmit a certain fund of knowledge and ability a pupil must acquire as something objective and indifferent to his or her individuality.

Although Simmel concedes that Kerschensteiner and he himself have a high estimation of individuality, he nevertheless sees two important differences.

One is that an individualization of subjects related to individual dispositional affinities is not really feasible, due to the enormous differences between individuals. And as he adds, it is not even desirable. Individuals should also learn to get acquainted and be confronted with subjects and matter which is in contrast to or different from their own dispositions and preferences. So not the subjects or the curriculum should be in the main focus of reform but much more the individuals as learners.

In these reflections Georg Simmel is quite closer to a concept of learning than in his rather cultural writings as displayed in his philosophical works.

Indeed, Georg Simmel saw the contrast between life and form. Life depends on forms, but in the long run life does not tolerate anything fixed, non-fluid. For that reason, a philosopher of life should have no interest in entities that persist for long periods of 
time. He has to try to reconcile form with content, what is rigid with what is movable, the solid with the fluid, and the boundary with what is unbounded, and to do so in such a manner "that ultimately life is what retains primacy". Simmel calls this conflict between life and form "the tragedy of culture", since life is forced to struggle constantly against its own products, which have taken on solidity and which no longer flow along with life's incessant streaming. It is in his view a "struggle of life for its own beeing. Where it expresses itself, it wishes only to express itself and nothing else, and thus breaks through every form" (Simmel, 1987: 158). Precisely in shedding previous forms, life is 'creative', but life "wishes to achieve something it cannot attain: It wishes to determine itself and appear over and beyond all forms, in the nakedness of its own immediacy - but knowing, wanting and shaping as determined by life can only substitute one form by another. It can never supplant form in general by life itself, as that which is beyond form" (Ibid., 172).

By reinserting this concept of culture, Simmel describes cultivation as an acceptance of supra-personal elements of content which, in secret harmony, only unfold in the soul what the psyche already contains and is pressing for its subjective realization and completion. Art and custom, science and objects formed in accordance with some purpose, religion and law, technology and social norms, are all stations the subject must pass through in order to acquire his "culture".

The "paradox of culture" is that subjective life, which is in a continuous flow, "presses out of our innermost being for its fulfilment - this fulfilment, viewed from the idea of culture, cannot be attained by itself but only via such forms that have now become so alien to it, crystallized to self-sufficient seclusion". (Simmel, 1983: 186)

In these selected remarks, we can see that Georg Simmel stresses those elements that Georg Kerschensteiner was able to make use of for his theory of education. Work emerges as the mediator par excellence between life pressing for inward fulfilment and perfection on the one hand and external form, so necessary for 
cultivation, on the other; in other words, work as the mediator between subjective psyche and objective intellectual product. But Simmel does not develop this cultural-critical dichotomy any further in anthropological concepts or psychological basic assumptions. Kerschensteiner thinks that he can read a whole theory of education into Simmel's concept of culture, he is referring to several times: "Culture is the way of the psyche to itself, from a unity closed in itself on through unfolded multiplicity to an unfolded and developed unity" (Simmel, 1983: 185).

Georg Simmel does not analyse, when it comes to pedagogy, a more general concept of learning and education (Bildung). As mentioned before, he refers to the "vital creative teacher" (Simmel, 1922: 10). That is why his lectures on "Schulpädagogik" appear quite 'traditional' in contrast to German progressive education. As Simmel stresses, it is most important that the teacher's pedagogical attitude should be "relevant for his practice". Simmel's Schulpädagogik had little in common with his other publications (see also Danner, 1991: 124 f.) and does not lead on to postulates of reforms and progressive education.

\section{Conclusion}

If we consider Simmel's attitude towards German progressive education, we can state that he is not referring to crucial concepts like child-centeredness, activity and creativity, youth movement and the cult of community ("Gemeinschaft"). Instead, he is focusing on specific aspects of education in schools. In so far Simmel's approach is quite typical of him. Like in aesthetics, when he delves into specific details, nevertheless he tries to make a theme of pivotal and often neglected elements of thinking about pedagogy in schools.

In a way, as Jürgen Habermas observed, Georg Simmel is not at all a systematic thinker but much more prefers an essayistic approach as a time diagnostician (Habermas, 1983: 247). Neither in sociology nor in philosophy he aims at developing a systematic building of thought but much more at establishing a practice- 
oriented and science-based actual approach to perceived topics. You could also argue that Simmel is trying to find a balance between his Kantian perspective of establishing a scientific world view on the one hand and a world view ("Weltanschauung") based on the Goethean relationship between the whole and the detail, a tension he described in his concise depiction "Kant und Goethe" (Simmel 1906).

That is why also his lectures on pedagogy are a mix of general problems like moral and the German essay, as well as sexual education, which are all included in his "Schulpädagogik". All in all, he marks a distance to his philosophical colleagues who try to establish a systematic pedagogy and to the progressive educationalists. He avoids any deeper discussion of the essentials of the progressive education of his time. His opposition is rather against religious bound educational thinking and a school system, which does not count on well-prepared teachers. Seen this way, he surprises his audience and readers with his unique approach.

\section{Bibliography}

Barth, P. (1912). Die Elemente der Erqiehungs- und Unterrichtslehre. Auf Grund der Psychologie und der Philosophie der Gegenwart. Leipzig: Johann Ambrosius Barth.

Barth, P. (1925). Die Geschichte der Erziehung in soziologischer und geistesgeschichtlicher Beleuchtung. Leipzig: O.R. Reisland.

Cohn, J. (1919). Geist der Erziehung - Pädagogik auf philosophischer Grundlage. Leipzig und Berlin: Teubner.

Danner, S. (1991). Georg Simmels Beitrag zur Pädagogik. Bad Heilbrunn: Klinkhardt.

Frischeisen- Köhler, M. (1921). Georg Simmel. In: Kant-Studien 24, 1, p. 1-51.

Frischeisen- Köhler, M. (1962). Philosophie und Pädagogik. Weinheim: Verlag Julius Beltz. 
Gonon, Ph. (2009). The Quest for Modern Vocational Education Georg Kerschensteiner between Dewey, Weber and Simmel. Bern: Peter Lang.

GSG 23. Georg Simmel Gesamtausgabe 23. Briefe 1912-1918. Jugendbriefe. Frankfurt: Suhrkamp. Georg Simmel an Georg Kerschensteiner. Brief vom 15. Oktober 1917, p. 843-845.

Habermas, J. (1983). Simmel als Zeitdiagnostiker. In: Georg Simmel (Hrsg.): Philosophische Kultur - Gesammelte Essais. Mit einem Nachwort von Jürgen Habermas. Berlin: Verlag Klaus Wagenbach, p. 243-253.

Hauter, K., (1922). Vorrede des Herausgebers. In: Karl Hauter (Hrsg.): Schulpädagogik - Vorlesungen gehalten an der Universität Strassburg von Georg Simmel. Osterwieck-Harz: Verlag von A. W. Zickfeldt, p. III-IV.

Hönigswald, R. (1927). Über die Grundlagen der Pädagogik. Ein Beitrag zur Frage des Pädagogischen Universitäts-Unterrichts. München: Verlag von Ernst Reinhardt.

Hönigswald, R. (1966 [1913]). Studien zur Theorie pädagogischer Grundbegriffe. Darmstadt: WBG.

Jerusalem, W. (1912). Die Aufgaben des Lehrers an böheren Schulen. 2nd new edition. Wien: Wilhelm Braumüller.

Kerschensteiner, G. (1926). Theorie der Bildung. Leipzig: Teubner Kerschensteiner, G. (1982). Georg Kerschensteiner Selbstdarstellung. In: Gerhard Wehle (Ed.): Texte zum Pädagogischen Begriff der Arbeit und zur Arbeitsschule. Paderborn: Schöningh, 110-149.

Köhnke, K. (1996). Der junge Simmel in Theoriebeziehungen und sozialen Bewegungen. Frankfurt: Suhrkamp.

Lichtwark, A. (1894). Wege und Ziele des Dilettantismus. Hamburg: Kunstshalle.

Natorp, P. (1904). Sozialpädagogik - Theorie der Willenserziehung auf der Grundlage der Gemeinschaft. Stuttgart. Frommanns Verlag. 
Natorp, P. (1909). Über Philosophie als Grundwissenschaft der Pädagogik. In: Philosophie und Pädagogik. Untersuchungen aufibrem Grenagebiet. 2nd Edition. Marburg: N.G. Elwert'sche Verlagsbuchhandlung.

Natorp, P. (1912). Allgemeine Psychologie nach kritischer Methode. Tübingen: Verlag J.C.B. Mohr.

Nelson, L. (1949). System der philosophischen Ethik und Pädagogik. 2. Edition. Göttingen u.a.: Verlag öffentliches Leben.

Rammstedt, O. \& Rammstedt, A. (2008). Comment to a postcard from Georg Simmel to Heinrich Rickert. 25.4. 1913. In: Rammstedt, O. \& Rammstedt, A. (Eds.): Georg Simmel - Briefe 1912-1918, GSG Vol. 23, p. 175-178.

Regener, F. (1910). Die Prinzipien der Reformpädagogik. Anregungen zu ibrer kritischen Würdigung. Berlin: Gerdes und Hödel.

Ritzel, W. (1980). Philosophie und Pädagogik im 20. Jahrbundert. Darmstadt: Wissenschaftliche Buchgesellschaft.

Rodax, K. (1999). Vorwort. In: Klaus Rodax (Hrsg.): Georg Simmel - Schulpädagogik. Vorlesungen gebalten an der Universität Straßbourg 1915/1916. Neu herausgegeben, eingeleitet und mit Anmerkungen versehen. Konstanz: UVK

Simmel, G. (1906). Kant und Goethe. [Cornelius Gurlitt (Ed.) Die Kultur - Sammlung illustrierter Einzeldarstellungen. Volume 10]. Berlin: Bard, Marquardt \& Co.

Simmel, G. (1918). Goethe. 3. Ed. Leipzig: Klinkhardt \& Biermann.

Simmel, G. (1922). Schulpädagogik. Vorlesungen gehalten an der Universität Strassburg. Osterwieck-Harz: A.W. Zickfeldt.

Spranger, E. (1909). Wilhelm von Humboldt und die Humanitätsidee. Berlin: Reuther \& Richard.

Stern, E. (1922). Einleitung in die Pädagogik. Halle: Verlag Max Niemeyer. 